\title{
RUBIO, Rocío Sánchez; NÚÑEZ, Isabel Testón; RUBIO, Carlos M. Sánchez (eds.). Imágenes de un Imperio Perdido : el Atlas del Marqués de Heliche - Plantas de diferentes Plazas de España, Italia, Flandres y las Indias. [Mérida], Presidencia de la Junta de Extremadura, 2004, 141 pp. + 246 pp. de ests.*
}

\author{
Francisco Roque de Oliveira \\ Centro de História de Além-Mar, Universidade Nova de Lisboa \\ Bolsista da Fundação para a Ciência e a Tecnologia
}

Apesar da existência do chamado Atlas do marquês de Heliche ser conhecida, há vários anos, por parte de um número restrito de especialistas em cartografia antiga ${ }^{1}$, os créditos pelo seu efectivo resgate e divulgação pública pertencem por direito próprio aos três responsáveis pela sua recente redescoberta ocasional e pela edição crítica ora saída a lume : as historiadoras Rocío Sánchez Rubio e Isabel Testón Núñez (Universidad de Extremadura) e o documentalista Carlos Sánchez Rubio. A obra em causa foi encadernada com o título "Plantas de diferentes Plazas de España, Italia, Flandres y Las Indias" e integra o espólio da secção Handritade Kartverk (vol. 25) do Arquivo Militar de Estocolmo, o Krigsarkivet. Este Atlas foi encomendado no início da década de 1650 por D. Gaspar de Haro y Guzmán, marquês de Heliche e, mais tarde, sétimo marquês del Carpio (1629-1687). Desenhou-o Leonardo de Ferrari, um relativamente obscuro pintor bolonhês residente em Madrid. O trabalho foi entre-

\footnotetext{
* Texto publicado em: Anais de História de Além-Mar, vol. 7, 2006, mantém a grafia original.

${ }^{1}$ Ver JOSEPHSON, Erland F.. Plantas de diferentes plazas... Presentation av en atlas på Krigsarkivet. In : Meddelanden från Krigsarkivet, 9, 1982, pp. 259-273; MÖRNER, Magnus \& MÖRNER, Aare, Spanien i svenska arkiv. Arkivguidel España en los archivos de Suecia. Guía de archivos. Estocolmo: Riksarkivet [Arquivo Nacional da Suécia], 2001, p. 44-49.
} 
gue ao marquês em 1655. Pouco depois da sua morte, passou para a posse do erudito e diplomata sueco Johan Gabriel Sparwenfeld (1655-1727), que o encaminhou para a Suécia em 1690 - talvez via Lisboa num barco sueco carregado de sal. Por decisão real, foi trasladado para o Krigsarkivet em 1880. É composto por 131 esboços de cidades e fortalezas, vistas, e representações de cercos e batalhas, correspondendo a 104 lugares distintos. Estes cobrem as principais fronteiras e zonas de tensão da Monarquia Hispânica, incluindo espaços europeus e ultramarinos entretanto perdidos de facto por efeito da restauração da independência de Portugal : Península Ibérica (guerras da Catalunha e Portugal), Itália, Flandres, França, Países Baixos e colónias ultramarinas (na América espanhola, na África e Índia portuguesas).

Sobrinho-neto do conde-duque de Olivares, de quem herdou o nome, e filho primogénito de D. Luis Méndez de Haro, principal ministro do rei Filipe IV de Espanha a partir de 1644, D. Gaspar de Guzmán viria a ser Grande Chanceler do Consejo de Indias, embaixador em Roma, Conselheiro de Estado e de Guerra e vice-rei de Nápoles. A sua figura cruzou-se por duas vezes com a história de Portugal : quando foi capturado pelos portugueses na batalha do Ameixial (1663) e quando, por indicação da regente Mariana de Áustria, agiu em Lisboa como plenipotenciário incumbido de assinar o tratado de paz entre Espanha e Portugal (1668). Em qualquer caso, este conjunto de desempenhos políticos e militares não chega a ser tão citado quanto a circunstância de ter sido um notável bibliófilo, um generoso mecenas do teatro e da música e um dos maiores coleccionadores privados de obras de arte da sua época - a época em que Filipe IV, a nobreza cortesã e até a burguesia de Espanha exibiram um interesse sem par pelo coleccionismo artístico, em particular pelo de natureza pictórica ${ }^{2}$. De resto, não será coincidência que o Atlas tenha sido encomendado a um pintor (que, manifestamente, reproduziu, uniformizou e embelezou um conjunto heteróclito de imagens de carácter militar que lhe foi cedido) e não a um engenheiro, arquitecto ou cosmógrafo (R. Sánchez Rubio et al., Plantas de diferentes Plazas..., p. 19-21).

A encomenda feita a Ferrari inscreve-se na primeira fase da vida de D. Gaspar, quando este ainda não desempenhara nenhuma das missões em que

${ }^{2}$ Ver ELLIOTT, J. H.. España y su mundo, 1500-1700. Traducción de Ángel Rivero Rodríguez y Xavier Gil Pujol. Madrid: Alianza Editorial, 1991, p. 334. 
mais tarde se destacou mas, em todo o caso, num momento em que, como monteiro-mor e gentil-homem da Câmara de sua Majestade, desfrutava da confiança de Filipe IV e talvez acalentasse a ambição de vir a suceder a seu pai com valido do rei. Encomenda privada, destinada a ser folheada num pequeno círculo cortesão, alia a representação coerente de informação militar sensível e a objectividade característica da "geografia utilitária" à qualidade própria da cartografia de "aparato" ou de "ostentação". Uma preocupação parece dominar a obra : representar apenas as vitórias e as praças conquistadas durante o valimiento do conde-duque de Olivares ou a privanza de D. Luis de Haro, ignorando derrotas e praças perdidas.

No prólogo à presente edição, o hispanista britânico John H. Elliott assinala a afinidade que este Atlas exibe com uma extensa série de obras cartográficas produzidas por encargo régio, a mais próxima das quais será a Descripción de España y de las costas y puertos de sus reynos compilada pelo cartógrafo português Pedro Teixeira, em 1634, a qual foi também recentemente impressa pela primeira vez (Prólogo, p. 15) ${ }^{3}$. Em qualquer caso, pensamos que esta última ideia deve ser matizada com a lembrança de que estes dois Atlas apresentam, apesar de tudo, claras diferenças entre si, tanto na temática e no espaço coberto pelas representações, como ao nível da qualidade do desenho. Seja como for, a propósito do carácter quase-régio da encomenda do Atlas de Heliche e da provável origem da generalidade dos materiais que a suportaram, importará acrescentar que o marquês não apenas teria acesso aos mapas e planos de cidades e fortalezas que pertenciam ao arquivo de trabalho do seu progenitor, como também ao fundo documental de Olivares, o qual passara para as mãos de D. Luis em 1650. Este incluía preciosidades como a colecção de mapas coloridos do cosmógrafo João Baptista Lavanha, a qual pouco depois foi cedida ao bibliófilo Cornelio Pedersen Lerche, embaixador da Dinamarca em Madrid (R. Sánchez Rubio et al., Plantas de diferentes Plazas..., pp. 21 e 28; p. 40, n. 111).

Nas citadas páginas introdutórias a esta edição, Elliott passa ainda em revista a conjuntura político-militar que enquadra a realização do trabalho de Ferrari e a forma como a aceleração dos acontecimentos nos cenários mais problemá-

${ }^{3}$ PEREDA, Felipe \& MARÍAS, Fernando (eds.). El Atlas del Rey Planeta. "La descripción de España y de las costas y puertos de sus reinos" de Pedro Teixeira (1634). Madrid: Editorial Nera, 2002. 
ticos, tanto na Europa como além-mar, parece ter forçado a conclusão apressada de um Atlas que se revestia de enorme interesse para a leitura que os ministros reais poderiam fazer sobre a localização e estado das defesas fronteiriças, portos e presídios da Monarquia (Prólogo, p. 16-17). A fracassada conferência de paz de Madrid (1656), que tentou resolver a contenda com a França e na qual D. Luis de Haro interveio como plenipotenciário de Filipe IV, pode ajudar a compreender o porquê da entrega de um Atlas inacabado (R. Sánchez Rubio et al, ibid., p. 21). Em qualquer caso, será difícil equacionar outro factor para além da urgência no acabamento da obra - ou, então, a hipótese do artista se ter visto subitamente impossibilitado prosseguir o seu labor - de modo a explicar a inclusão de três planos de Cádis contra nenhum de Lisboa, de Barcelona ou do reino de Nápoles, relativamente poucos da Flandres e igualmente nenhum de Cadaqués, sitiada e tomada pelos franceses na Primavera de 1655. Aliás, basta passar os olhos pelo traço hiper-esquemático ou pelas molduras vazias de legendas de muitos dos seus desenhos para se chegar a idêntica conclusão.

No segundo artigo colectivo que assinam neste volume, os seus editores recapitulam as grandes linhas da política exterior da Monarquia Hispânica delineadas no princípio da década de 1620, sob a batuta de Olivares, as quais viriam a ser irrevogavelmente condicionadas a partir de meados da década seguinte, quando o início do despique hispano-francês pela supremacia na Europa acabasse por se repercutir em vários dos principais espaços do império (Itália, Países Baixos meridionais, Portugal e Catalunha, em particular), forçando a queda do conde-duque e levando à gestão menos activa e intervencionista nos assuntos europeus que Haro protagonizou na segunda metade do reinado de Filipe IV - e, em definitivo, depois da derrota sofrida em Rocroi pelo exército espanhol da Flandres (1643) ter oficializado o crepúsculo da Espanha. Como se recorda nesse texto, a efémera recuperação espanhola diante da França que acontece nos anos da Fronda tem o seu ponto alto no começo da década de 1650, quando Filipe IV logrou anular a política italiana de Mazarino, recuperou praças vitais nos Países Baixos meridionais e reconquistou a maior parte da Catalunha. Ora - e como insistem os mesmos autores - esse fogo-fátuo de vitórias coincide precisamente com a encomenda feita a Ferrari (R. Sánchez Rubio et al., Las imágenes del Atlas en su contexto histórico, p. 39-41).

Cerca de dois anos depois do Atlas ter sido encadernado e confiado a quem o encomendara, Filipe IV aproveita a morte de D. João IV para lançar a invasão de Portugal a partir da Estremadura espanhola, campanha reatada no ano seguinte sob comando do próprio D. Luis de Haro e que terminará com a vi- 
tória portuguesa de Elvas (Janeiro de 1659). Pouco depois de ter sofrido essa derrota pesada na frente lusa, caberá ainda a D. Luis negociar e assinar com o cardeal Mazarino o Tratado dos Pirenéus (Novembro de 1659) - e, com as garantias obtidas na ilha dos Faisões, ganhar novo ânimo para ponderar a rápida reconquista de Portugal ${ }^{4}$. Entre os estudos que acompanham este livro, inclui-se um clássico texto de Antonio Domínguez Ortiz (1959) consagrado a esse tratado que veio pôr fim a quase um quarto de século de guerra aberta entre a França e a Espanha. Tornam a poder ler-se aí alguns dos aspectos mais relevantes da conjuntura que enquadrou o encargo do Atlas de Heliche, perspectivando-se com particular clareza o modo como a cedência espanhola a tais negociações denunciou um império exangue (España ante la Paz de los Pirineos, p. 77-88).

Não menos reveladora é a reconstituição do contexto que favorece a compra do Atlas por parte de Sparwenfeld quando este visitou Madrid em missão instruída pelo rei Carlos XI da Suécia para a pesquisa de antiguidades godas e a decifração dos vínculos que, na linha de Olof Rudbeck e da sua célebre Atlântida (Upsala, 1679-1702), os goticistas sustentavam existirem entre os reis visigodos e os escandinavos ${ }^{5}$. Os termos gerais desta viagem (1689-1690) sãonos oferecidos pelos três editores desta obra (R. Sánchez Rubio et al., Plantas de diferentes Plazas..., p. 30-31), enquanto Magnus Mörner se encarrega da sua análise circunstanciada (La adquisición sueca del Atlas por Johan Gabriel Sparwenfeld, p. 105-109). Para o que mais nos importa, haverá que notar que, entre os muitos livros e documentos adquiridos pelo erudito sueco aos livreiros de Madrid, coleccionadores particulares ou aos herdeiros da Casa del Carpio encontravam-se alguns dos planos e mapas originais manuseados por Ferrari para a composição do Atlas (entre os quais as plantas do Forte de S. Julião da Barra e de Lagos), diverso material cartográfico executado para D. Gaspar pelo engenheiro militar Ambrosio Borsano, assim como um "Compendium geographicum", correspondente a uma primeira versão do sumptuoso Atlas que Pedro Teixeira entregou ao rei em 1634, esta dedicada ao primeiro marquês de

\footnotetext{
${ }^{4}$ Ver VALLADARES, Rafael. La rebelión de Portugal. Guerra, conflicto y poderes en la Monarquía Hispánica (1640-1680). Valladolid: Junta de Castilla y León, 1998, pp. 161-168.

${ }^{5}$ Ver VIDAL-NAQUET, Pierre. L'Atlantide. Petite histoire d'un mythe platonicien. Paris : Les Belles Lettres, 2005, pp. 75-78 e 83-96.
} 
Leganés (hoje na Biblioteca da Universidade de Uppsala e que também só há poucos anos foi editado) ${ }^{6}$.

A despeito da escassez de dados disponíveis - ou precisamente por isso -, outro tanto há a dizer do breve inquérito apresentado sobre a esquiva figura de Leonardo de Ferrari. É aventada a hipótese de se tratar de um discípulo do pintor Lucio Massai sobretudo conhecido pela obra de temática religiosa que se encontra dispersa por várias igrejas e conventos de Bolonha, mas também versátil noutros géneros, como a caricatura. Nesse sentido, ganha particular interesse a sugestão que associa a sua presença em Madrid ao ressurgimento da actividade teatral que decorre do matrimónio de Filipe IV com Mariana de Áustria e à forte influência italiana que os géneros teatrais e cenográficos cortesãos receberam nessa época dourada. E é a propósito disto mesmo que se evocam as funções que competiam ao marquês de Heliche como Alcaide, que também era, de quase todas casas de campo do monarca, funções que o levaram a projectar algumas das mais espectaculares representações e festas a que a Corte então assistiu (R. Sánchez Rubio et al., "Plantas de diferentes Plazas...", pp. 31-32)7.

Como começámos por referir, a geografia dos pouco mais de 100 lugares cobertos pelas representações insertas no Atlas do marquês de Heliche traduz aquelas que eram então as frentes mais problemáticas da Monarquia Hispânica. Ainda que a ordenação dos respectivos planos no interior do códice não seja exactamente esta, temos o seguinte para o espaço europeu e periferia magrebina : na Península Ibérica, as fronteiras pirenaica, catalã e portuguesa (apesar de tudo, a frente portuguesa é relativamente pouco representada no Atlas, talvez em resultado de se estar perante uma frente de guerra "congelada"); em Itália, os presídios da Toscana, o controlo do "caminho espanhol" (entre Génova/Finale e o passo alpino de Valtelina) e, sobretudo, o Estado de Milão e territórios limítrofes; nos Países Baixos, Dunquerque, Mardick, Courtrai e Flesinga (como dito, outro caso de clara sub-representação de um espaço de grande valor estratégico para a

\footnotetext{
${ }^{6}$ TEIXEIRA, Pedro. Compendium geographicum. Madrid : Fundación Alvargonzález; Museo Naval; Uppsala Universitet, 2001.

${ }^{7}$ Ver BÉNÉZIT, E. Dictionnaire critique et documentaire des peintres, sculpteurs, dessinateurs et graveurs de tous les temps et de tous les pays. vol. 3, Paris : Librairie Gründ, 1955, p. 724; STEIN, Louise K. "Música”, In : CASA, Frank P. et al. (dirs.). Diccionario de la comedia del Siglo de Oro. Madrid: Editorial Castalia, 2002, p. 221.
} 
Monarquia, talvez explicável pelo facto do Atlas ter sido idealizado após a assinatura da paz de Münster); as fortificações sicilianas, vitais para a defesa do Mediterrâneo, tal como os enclaves norte-africanos de Orão, Mazalquivir, Mamora e Tânger, decisivos para a guarda do estreito de Gibraltar; e as praças peninsulares atlânticas de Cádis, Aiamonte, Castro Marim, Tavira, Lagos e S. Gião (ou Julião da Barra), que haviam permitido aos Áustrias assegurar o funcionamento da Carrera de Indias, controlar as costas do Algarve e o acesso marítimo a Lisboa. Aqui, importará assinalar que, ao invés do pretendido pelos editores desta obra, nem S. Gião foi erigido em local escolhido por Filipe II de Espanha (confusão entre o Bugio e as obras de ampliação da Torre de S. Julião gizadas durante o domínio filipino pelo engenheiro militar Giacomo Palearo ou "Fratino"8), nem Lagos corresponde a um "enclave localizado en el cabo de San Vicente" (entre o mais, confusão com Sagres) - cf. R. Sánchez Rubio et al., "Las imágenes del Atlas...”, pp. 66 e 67.

Entre as 56 plantas de cidades, 48 fortalezas e enclaves defensivos, 18 desenhos corográficos em forma de vistas com carácter paisagístico e 9 cenários de batalhas que integram este Atlas, apenas dez imagens ilustram espaços do desaparecido império colonial hispano-português. Uma vez mais, a sua aparente qualidade de trabalho interrompido extemporaneamente poderá justificar a escassa lista de territórios africanos, asiáticos e americanos representados por Ferrari. Callao (Lima) e duas fortificações da cidade de Havana (Morro e San Salvador) são as únicas praças americanas presentes, não constando sequer Santo Domingo e Cartagena de Indias. As restantes correspondem às cidades ou às fortalezas da Ribeira Grande, na ilha cabo-verdiana de Santiago, S. Jorge da Mina (à data já em mãos holandesas), Moçambique e Damão.

Conhecendo vários dos mapas e planos originais utilizados por Ferrari, sabemos que, regra geral, este copiou de forma fiel os respectivos modelos, respeitando o ângulo com que haviam sido traçados, a que muitas vezes se seguiu a recriação do entorno com recurso a mais do que um ângulo de visão. Trata-se de uma técnica cartográfica habitual, mas que, ao não ter sido aplicada pelo

\footnotetext{
${ }^{8}$ Ver GUEDES, Lívio da Costa. Aspectos do Reino de Portugal nos séculos XVI e XVII - A "Descripção" de Alexandre Massaii (1621), vol. 2, Tratado. Lisboa: Arquivo Histórico Militar, 1989, p. 138, n. 98; CALLIXTO, Carlos P. São Julião da Barra - Os primeiros anos. Lisboa: Câmara Municipal de Oeiras, 1990, pp. 9-36 e 51-53.
} 
italiano segundo um critério uniforme, acaba por traduzir uma liberdade mais própria de um pintor que de um cartógrafo profissional (R. Sánchez Rubio et al., "Plantas de diferentes Plazas...", pp. 35-36). Apesar de tudo, a sua "Planta de la Civda. de Cabo Verde" (est. 61) é um bom exemplo daquilo que de melhor nos oferece, devendo ser notado que a mesma apresenta semelhanças assinaláveis com a gravura da Ribeira Grande de Johannes van Keulen (c. 1635) que pertence à colecção de iconografia do Arquivo Histórico Ultramarino (Lisboa) ${ }^{9}$. Em contrapartida, nenhuma das três detalhadas plantas de S. Jorge da Mina que constam do Atlas de Heliche (ests. 64-66) tem o que quer que seja em comum com esquemas como os propostos por Georg Braun-Jan Jansson, O. Dapper, Caspar Barläeus ou Johannes Vingboons nem - por maioria de razão - com as anteriores representações simbólicas dessa fortaleza, insertas na generalidade das cartas portuguesas de pequena escala ${ }^{10}$.

A nosso ver, a sua "Planta de Monsãbiqve" (est. 62) patenteia outro caso interessante : além de bastante mais apurada que as aguarelas pertencentes às sucessivas versões do Livro das Plantas das Fortalezas do Estado da Índia Oriental (onde sabemos que se mesclam os protótipos utilizados por Godinho de Erédia, António Bocarro, Barreto de Resende e João Teixeira) ${ }^{11}$, é-o também em relação ao desenho de "Moçambique" que integra o Atlas de Erédia guardado na Biblioteca Nacional do Rio de Janeiro, o qual corresponde à mais antiga colectânea conhecida de plantas das praças portuguesas do Oriente ${ }^{12}$. Já na planta de "La Civdad de Damão" (est. 67) assinada por Ferrari começamos por reconhecer a trace italienne da sua imponente muralha em forma de decágono irregular orientado no sentido nascente-poente, com dez bastiões em espigão, encerrando uma malha urbana ortogonal, cuja referência é dada pelo qua-

\footnotetext{
${ }^{9}$ Rep. in ALBUQUERQUE, Luís de \& SANTOS, Maria Emília Madeira (coords.). História Geral de Cabo Verde, vol. 1. Lisboa/Praia: Instituto de Investigação Científica Tropical; Direcção Geral do Património Cultural de Cabo Verde, 1991, capa e contracapa. Cf. MOTA, Avelino Teixeira da. Cinco séculos de cartografia das ilhas de Cabo Verde. In: Garcia de Orta, 9 (1), 1961, ests. 5-7.

${ }^{10}$ Ver SILVEIRA, Luís Ensaio de Iconografia das Cidades Portuguesas do Ultramar, vol. 2, África Ocidental e África Oriental. Lisboa: Junta de Investigações do Ultramar, s.d. [1950], ests. 203-211.

${ }^{11}$ Ver id., ibid., ests. 437, 439, 440, 444, 445, 451 e 452.

${ }^{12}$ Ver id., ibid., est. 435.
} 
drado do (reformado) fortim muçulmano preexistente. Em todo o caso, também aqui o desenho incluído no Atlas de Heliche parece desentender-se da iconografia mais divulgada : por um lado, representa com particular cuidado a área envolvente da cidade-fortaleza de Damão, mas falha o traçado da planta do Forte de S. Jerónimo, elevado na margem norte do rio Sandalcalo em 1614$1627^{13}$; por outro, representa a quadrícula urbana de um modo bastante mais preciso do que qualquer das versões conhecidas do Livro das Plantas que retomam o modelo de Erédia ${ }^{14}$; por último, no Atlas surge traçado com cor diferente o que parece ser o projecto de uma segunda muralha de feição italiana, hexagonal, sendo que quatro das suas faces interceptam a retícula quase geometricamente perfeita da malha urbana intramuros, enquanto as restantes se sobrepõem a parte substancial das muralhas do lado do mar.

No derradeiro dos ensaios académicos que introduzem esta primeira edição do Atlas de marquês de Heliche, Richard L. Kagan disserta sobre a estreita ligação que terá existido entre a afirmação no vocabulário político da Europa, ao longo do século XVII, do conceito de soberania territorial, os esforços que vários Estados então desenvolvem no sentido de conseguirem um maior conhecimento tanto de geografia como de cosmografia e, finalmente, o aparecimento da denominada "cartografia oficial" na Corte de Filipe IV. Sem esquecer a tradição vinda dos tempos de Carlos V e, sobretudo, do reinado de Filipe II - durante o qual os mapas se converteram, em definitivo, num instrumento recorrente de governo ${ }^{15}$-, Kagan cita o empenho que Filipe III colocou no estudo das costas algarvias, brasileiras e da Terra do Fogo e termina detendose na série de ambiciosas encomendas cartográficas impulsionadas a partir do ministério de Olivares, todas elas de claro perfil político e estratégico e, por isso mesmo, por regra representativas da categoria dos arcana imperii, ou segredos do monarca : as várias versões da referida Descripción de España de Pedro

\footnotetext{
${ }^{13}$ Ver CHOUKROUN, Sabine. Damão: a Fortaleza e o seu Distrito. In : CUNHA, Mafalda Soares da (coord.). Os Espaços de um Império - Estudos. Lisboa: Comissão dos Descobrimentos, 1999, p. 133-135.

${ }^{14}$ Ver SILVEIRA, L. Ensaio de Iconografia, vol. 3, Ásia Próxima e Ásia Extrema. Lisboa: Junta de Investigações do Ultramar, s.d. [1956], ests. 510, 552-556; CORTESÃO, Armando \& MOTA, Avelino Teixeira da (eds.). Portugaliae Monumenta Cartographica, vol. 4. Lisboa: s./ed., 1960, ests. 471F e 511; idem, ibidem, vol. 5, ests. 583E, 583F e 383G.

${ }^{15}$ Ver PARKER, Geoffrey. El éxito nunca es definitivo. Imperialismo, guerra y fe en la Europa moderna. Traducción de Marco Aurelio Galmarini y Pepa Linares. Madrid: Taurus, 2001, p. 101.
} 
Teixeira; o Livro que dá razão do Estado do Brasil (c. 1627) de João Teixeira Albernaz (códice que se encontra no Rio de Janeiro e cujo frontispício ostenta o escudo de armas do segundo marquês de $\mathrm{Heliche}^{16}$ ); os vários Atlas universais atribuídos ao mesmo João Teixeira que têm no datado de $c .1628$ ("Atlas Duchesse de Berry") o mais antigo exemplar conhecido ${ }^{17}$; os mapas e planos da Vista de las Islas y Reyno de la Gran Canaria (1634) de Iñigo de Briçuela e Prospero Casola Cota; enfim, o próprio Atlas de Heliche, que aqui se considera que seguiu o conceito e o desenho da obra de Nicolas (alias Christophe) Tassin Les Plans et profils de toutes les principales villes et lieux considerables de France (Paris, 1634), cuja cópia figurava na biblioteca privada de Filipe IV (R. L. Kagan, "La cultura cartográfica en la corte de Felipe IV", pp. 91-101) ${ }^{18}$. A estes exemplos deveríamos agregar objectos como o assinalado Livro das Plantas que o cronista da Índia Portuguesa António Bocarro compilou em 1635 a pedido do rei.

É ainda Kagan quem nos lembra o ponto decisivo da relativa escassez de mapas produzidos em Espanha durante o século XVII, associando esse aparente paradoxo à manutenção em vigor da antiga política de sigilo cartográfico que vinha dos tempos de Fernando e Isabel. A propósito, sublinha as nefastas consequências que daí advieram para a indústria privada da cartografia e, em última análise, para a qualidade global dos mapas. Como também escreve, não será por acaso que os principais cartógrafos ou desenhistas associados a Filipe IV são estrangeiros : Lavanha e os irmãos Teixeira, portugueses; Casola Cota e Ferrari, italianos; Jan Karel Della Faille, flamengo (R. L. Kagan, ibid., pp. 101-103) ${ }^{19}$.

Naturalmente, nem mesmo a afamada colecção de obras cartográficas que Filipe IV reuniu na Torre Alta do Alcázar de Madrid - catalogando autores como De Veer, Ortelius, Braun-Hogenberg, Rosaccio, Sgrooten ou o supradito

${ }^{16}$ Ver CORTESÃO, A. \& MOTA, A. T. da. Portugaliae Monumenta Cartographica, vol. 4, p. 99-101.

${ }^{17}$ Ver idem, ibidem, p. 79-91, 107-118 e 123-124.

${ }^{18}$ Ver PASTOUREAU, Mireille. Les Atlas français XVIe-XVIIe siècles - Répertoire bibliographique et études. Paris : Bibliothèque nationale, 1984, p. 437, 451-467.

${ }^{19}$ Sobre J. K. Della Faille, ver: NAVARRO BROTÓNS, Víctor. Los jesuitas y la enseñanza, asimilación y difusión de los saberes y prácticas científicas en la España del siglo XVII. In: CAROLINO, Luís Miguel \& ZILLER-CAMENIETZKI, Carlos (coords.). Jesuítas, Ensino e Ciência. Séculos XVI-XVII. Casal de Cambra/Évora, Caleidoscópio; Centro de Estudos de História e Filosofia da Ciência da Universidade de Évora, 2005, p. 147-150. 
Tassin, por exemplo ${ }^{20}$ - serve para elidir esta realidade. Também não é suficiente para tanto a constatação de que grandes personagens da Corte, como Heliche, no seu afã de emularem o gosto régio pelos mapas, acabaram reunindo um número maior ou menor de composições cartográficas. É que o marasmo verificado na cartografia já pesava tanto ou tão pouco nesta época que dava azo a episódios como o protagonizado pelo cosmógrafo real de Espanha J. K. Della Faille, que na década de 1630 tratou de convencer o monarca a submeter a província da Holanda baseando-se para tanto no Atlas de Mercator $^{21}$... O preço de tudo isto será elevadíssimo, conforme se percebe notando que, quando se chega ao reinado de Filipe $\mathrm{V}$, além de não existir um mapa geral da Espanha, quase não existe cartografia válida para a América e para as possessões do Pacífico, do mesmo modo que faltam à armada espanhola as mais elementares cartas hidrográficas ${ }^{22}$.

Até pela escassíssima colecção de cartas de praças ultramarinas que incorpora, o Atlas do marquês de Heliche espelha bem a decadência inexorável da tradição cartográfica nacional. O mais corrente é inferir daqui que tal situação era tão-só o reflexo do declínio da posição internacional da Espanha que decorre entre os reinados de Filipe II e Filipe IV. Foi Geoffrey Parker quem, a propósito disto, ensaiou a leitura inversa, ao sustentar que a indigência em que ia caindo a cartografia espanhola funcionava, antes do mais, como agente da própria decadência da monarquia : "Um governo que carecia de ferramentas cartográficas necessárias para organizar os seus recursos e para projectar o seu poder, e que recorria, em contrapartida, a Atlas gerais antiquados para o planeamento estratégico, já não era uma potência imperial convincente"23. Visto por este prisma, o título dado a esta obra - Imágenes de un Imperio Perdido - ganhará ainda mais sentido.

\footnotetext{
${ }^{20}$ Ver BOUZA, Fernando. Cultura de lo geográfico y usos de la Cartografía entre España y los Países Bajos durante los siglos XVI y XVII. In : De Mercator a Blaeu - España y la edad de oro de la cartografía en las Diecisiete Provincias de los Países Bajos. Barcelona: Institut Cartogràfic de Catalunya, 1995, p. 58-59.

${ }^{21}$ Ver PARKER, G. El éxito..., p. 122.

${ }^{22}$ Ver NÚNẼZ DE LAS CUEVAS, Rodolfo. Historia de la cartografía española. In : La cartografia de la Península Ibèrica i la seva extensió al continent americà. Barcelona: Institut Cartogràfic de Catalunya, 1991, p. 187.

${ }^{23}$ PARKER, G. El éxito..., cit. p. 122.
} 